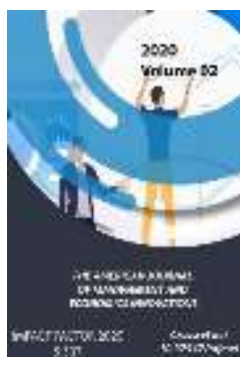

Journal Website: http://usajournalshub.c om/index,php/tajmei

Copyright: Original content from this work may be used under the terms of the creative commons attributes 4.0 licence.

\section{Fundamentals Of Improving Strategic Management In The Energy Sector Of The Republic Of Uzbekistan}

\author{
Juraev J.T \\ Academy Of Public Administration Under The President Of The Republic Of Uzbekistan
}

Tleumuratov J.B

Head Of The ERP Implementation Group Of Uzbekneftegaz JSC, Uzbekistan

\title{
ABSTRACT
}

Uzbekistan is developing its nuclear and regulatory infrastructure in strong partnership with the International Atomic Energy Agency (IAEA) to widen the energy capacity, the country aims for becoming the leader of the energy sector in Central Asia. Thus, Uzbekistan needs a polished policy of management and strategies to have an environment like that they are planning, and of course to implement this, the strategic management is necessary and clarifying the problems in managing the energy sector of the state is also of high essentiality. Taking this into consideration, this not huge paper will be oriented for illuminating such issues.

\section{KEYWORDS}

Policy of management, financial situation, domestic customers, crisis.

\section{INTRODUCTION}

This topic is so ground-breaking because Uzbekistan is aiming for becoming the leader of the energy sector in Central Asia and the country is willing for creating the harmonious business climate and atmosphere for the foreign investors. Nevertheless, especially strategic management in this field of study and economic sector has not been examined more by the scientists of Uzbekistan and others feel like it is important.

While writing this paper, the author used many sources of information which are like: world energy web-site and other articles of the specialists, to improve the strategic situation of the firm or any enterprise. Besides that, Alisher Sultonov, the minister of the energy of 
the Republic of Uzbekistan and the report of the ministry were used to write and gather data.

Likewise, Uzbekistan has been implementing large-scale reforms in recent years to strengthen its energy industry. Problems are associated with high wear and tear on equipment as well as with the slow pace of infrastructure updates, faulty equipment operations, inadequate installations, and both gas pipelines and power lines that have exceeded their service life. The country's unstable financial situation and inadequate introduction of resource- and energy-saving technologies have raised technological losses and made fuel and energy resource supply interruptions more frequent.

\section{MATERIALS AND METHODS}

Some years ago, Uzbekistan did not provide the true and reliable information about its energy sector, that is why, to have a correct piece of data. However, the Statistics Committee of Uzbekistan has become active in international forums in recent years. Having said that, there are other problems too: Low efficiency of TPP-All TPPs run on steam turbine technology with a weight average efficiency of $33 \%$, compared to $55 \%$ for advanced combinedcycle gas turbine technology; Poor assets condition. Most power generation assets are 40-50 years old, in poor condition, and require replacement and/or rehabilitation. Power assets are not strategically situated. About 70\% of power generation occurs in the north while over $90 \%$ of gas production occurs in the south; Assets have not been properly maintained and upgraded, affecting the delivery of reliable power supply to domestic customers, especially in the south regions; High level of losses. Transmission system losses are officially reported at $18 \%$ and distribution losses at $14 \%$; Revenue collection rate is not more than $80 \%$ which may be understated because of UzbekEnergy's inability to collect information on the amount of electricity supplied and inability to monitor the revenue collection; Low tariffs.
Uzbekistan's electricity tariff has been low in absolute terms because of the low domestic cost of natural gas relative to international prices. This has discouraged demand-side energy efficiency improvements. By the same token, if we continue going in the counting the problems or just one looks at the management of the energy sector. Lack of integrated energy planning and demand forecasting seriously worsening gap between energy supply and demand. Imbalanced energy: mix with heavy dependence on oil and gas. Non-utilization of vast indigenous resources of charcoal, solar, wind and hydro at the potential.

\section{RESULT AND DISCUSSION}

All the problems stated above might be resolved by implementing a strong strategic management items and endeavours.

First and foremost, it is natural and indispensable that the country should promote domestic alternate sources of energy including Hydro, solar, wind, local coal, agriculture, biomass/biodiesel etc. to supply the forthcoming businesses.

- Energy conservation and demand management programs;

- $\quad$ Coping with circular debt and better management of power sector financial flows;

- $\quad$ Existing power plants to be overhauled to achieve maximum efficiency;

- $\quad$ Undertake policies and programs to improve governance, performance of energy sector entities;

- $\quad$ Ensure operational/financial integrity of the sector.

- $\quad$ Penalties for electric thefts.

\section{CONCLUSION}

Or else, Uzbekistan is planning its roadmap to get out of this kind of crisis and creating some strategies to improve its energy sector. To accomplish the task, Uzbekistan has already initiated a few real steps and the government is try to improve, but in terms of the strategic 
The American Journal of Management and Economics Innovations (ISSN - 2693-0811)

Published: November 30, 2020 | Pages: 16-18

Doi: https://doi.org/10.37547/tajmei/Volumeo2Issue11-02

management, the country should keep an eye for setting a clear and exact goals within the specific period of time.

\section{REFERENCES}

1. https://www.energycharter.org/filead min/DocumentsMedia/News/20181004 _Uzbekistan_s_energy_sector.pdf

2. $\bar{h}$ ttps://world-nuclearnews.org/Articles/Uzbekistan-on-trackfor-IAEA-mission-this-year,-sa

3. https://www.altenergymag.com/articl e/2018/05/energy-management-issueschallenges-and-way-forward-inpakistan $/ 28593$

4. https://www.iea.org/reports/uzbekista n-energy-profile

5. https://smallbusiness.chron.com/fivestages-strategic-management-process18785.html 